\title{
Diagnostic Testing for Differential Diagnosis in Thrombotic Microangiopathies
}

\author{
Trombotik Mikroanjiyopatilerde Ayırıcı Tanı Için Tanı Testi
}

\author{
(D) Gina Zini1,2, (D) Raimondo De Cristofaro1,3 \\ ${ }^{1}$ Fondazione Policlinico Universitario A. Gemelli IRCCS - Rome, Italy \\ 2 Institute of Hematology, Università Cattolica del S. Cuore, Rome, Italy \\ 3Institute of Internal Medicine and Geriatrics, Università Cattolica del S. Cuore, Rome, Italy
}

\section{Abstract}

Thrombotic microangiopathies (TMAs) are multiple disease entities with different etiopathogeneses, characterized by thrombocytopenia, microangiopathic hemolytic anemia (MAHA) with schistocytosis, variable symptoms including fever, and multi-organ failure such as mild renal impairment and neurological deficits. The two paradigms of TMAs are represented on one hand by acquired thrombotic thrombocytopenic purpura (TP) and on the other by hemolytic uremic syndrome (HUS). The differential diagnosis between these two paradigmatic forms of TMA is based on the presence of either frank renal failure in HUS or a severe deficiency $(<10 \%)$ of the zincprotease ADAMTS13 (a disintegrin and metalloproteinase with a thrombospondin type 1 motif, member 13) in TTP. ADAMTS13 is an enzyme involved in the proteolytic processing of von Willebrand factor (vWF), and its deficiency results in formation of highmolecular-weight vWF-rich microthrombi in the environment of the microvasculature. The presence of these ultra-large vWF multimers in the microcirculation can recruit platelets, promoting multi-organ ischemic lesions. The presence of ADAMTS13 activity at $>10 \%$ could rule out the presence of a TTP form. However, it is often difficult to differentiate either a TTP or HUS clinical scenario presenting with typical symptoms of TMA. There are in fact several additional diagnoses that should be considered in patients with ADAMTS13 activity of $>10 \%$. Widespread inflammation with endothelial damage and adverse reactions to drugs play a central role in the pathogenesis of several forms of TMA, and in these cases, the differential diagnosis should be directed at the underlying disease. Hence, a correct etiologic diagnosis of TMA should involve a critical illness, cancer-associated TMA, drug-induced TMA, and hematopoietic transplant-associated TMA. A complete assessment of all the possible etiologies for TMA symptoms, including acquired or congenital TT, will allow for a more accurate diagnosis and application of a more appropriate treatment.

Keywords: Microangiopathic hemolytic anemia, Thrombotic microangiopathies, Anemia

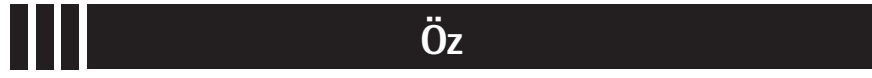

Trombotik mikroanjiyopatiler (TMA), farklı etiyopatogenezleri olan; trombositopeni, şistositlerin eşlik ettiği mikroanjiyopatik hemolitik anemi (MAHA), ateş, hafif böbrek yetmezliği ve nörolojik defisitler gibi çoklu organ tutulumlarıla karakterize bir hastalıklar grubudur. TMA'ların iki paradigması bir yandan edinsel trombotik trombositopenik purpura (TTP) ve diğer yandan hemolitik üremik sendrom (HUS) ile temsil edilir. TMA'nın bu iki paradigmatik formu arasındaki ayırıcı tanı, HUS'de belirgin böbrek yetmezliği veya TP'de çinko-proteaz ADAMTS13'ün (bir disintegrin ve metalloproteinaz trombospondin tip 1, üye 3) ciddi eksikliğinin $(<\% 10)$ varlığına dayanmaktadır. ADAMTS13, von Willebrand faktörünün (vWF) proteolitik işleminde yer alan bir enzimdir ve eksikliği, mikrovasküler ortamda yüksek molekül ağırlıklı vWF bakımından zengin mikrotrombüs oluşumuna yol açar. Bu ultra-büyük vWF multimerlerinin mikro dolaşımdaki varlığı, trombositleri toplayarak çok organlı iskemik lezyonları teşvik eder. ADAMTS13 aktivitesinin \%10'dan büyük oluşu, bir TTP formunun varlığını dışlatabilir. Bununla birlikte, tipik TMA semptomları gösteren bir TTP veya HUS klinik senaryosunu ayırt etmek genellikle zordur. Aslında ADAMTS13 aktivitesi \%10'dan büyük olan hastalarda göz önünde bulundurulması gereken birkaç ek tanı vardır. Endotel hasarı ve ilaçlara verilen yan etkilerle birlikte görülen yaygın yangı, birçok TMA formunun patogenezinde merkezi bir rol oynamaktadır ve bu durumlarda, ayırıcı tanı altta yatan hastalığa yönlendirilmelidir. Bu nedenle, TMA'nın doğru bir etiyolojik tanısı, kritik bir hastalık, kansere bağlı TMA, ilaca bağlı TMA ve hematopoetik transplant ile ilişkili TMA'yı içermelidir. Edinilmiş veya konjenital TP dahil olmak üzere TMA semptomları için olası tüm etiyolojilerin tam bir değerlendirmesi, daha uygun bir tedavinin daha doğru bir şekilde teşhis edilmesine ve uygulanmasına olanak sağlayacaktır.

Anahtar Sözcükler: Mikroanjiyopatik hemolitik anemi, Trombotik mikroanjiyopatiler, Anemi

๑Copyright 2019 by Turkish Society of Hematology

Turkish Journal of Hematology, Published by Galenos Publishing House

Address for Correspondence/Yazışma Adresi: Gina ZINI, M.D., Fondazione Policlinico Universitario A. Gemelli IRCCS - Rome, Italy

Phone : +390630153262

E-mail : gina.zini@unicatt.it ORCID: orcid.org/0000-0003-0782-294X

Received/Geliş tarihi: April 26, 2019 Accepted/Kabul tarihi: July 22, 2019 


\section{Introduction}

The name thrombotic microangiopathy (TMA) refers to rare multisystem diseases characterized by damage of endothelial walls of arterioles and capillaries, which leads to massive occlusion and formation of platelet-rich thrombi and microangiopathic hemolytic anemia (MAHA). By definition, TMA indicates neither a specific diagnosis nor a specific etiology; it is just a pathologic diagnosis made by tissue biopsy $[1,2]$. TMAs are medical emergencies requiring rapid diagnosis and appropriate treatment.

The term MAHA refers to nonimmune hemolytic anemia caused by red blood cell (RBC) intravascular fragmentation. This is combined with:

- schistocytosis, with a confidence threshold of $1 \%$ in peripheral blood to support a clinical diagnosis of TMA $[3,4]$;

- consumption thrombocytopenia with platelets of $<150 \times 10^{9}$ or a decrease from baseline of $>25 \%$.

- negative direct antiglobulin test (DAT);

- indirect indicators of hemolysis, such as increased plasma lactate dehydrogenase (LDH), and/or decreased hemoglobin and/or haptoglobin;

- fever and organ involvement, including renal impairment and/or neurological, gastrointestinal, cardiovascular, pulmonary, or visual symptoms.

Not all cases of MAHA are caused by a TMA, but all TMAs cause MAHA and thrombocytopenia.

\section{History}

Moschcowitz in 1924 described for the first time a case of abrupt onset and progression of petechial bleeding, pallor, fever, paralysis, hematuria, and coma [5], with disseminated microvascular hyaline thrombi in arterioles and capillaries. In 1947 Singer et al. [6] first introduced the term "thrombotic thrombocytopenic purpura" (TTP). The name TMA was introduced by Symmers in 1952 to describe the vascular lesions observed in TTP [7]. In 1955 Gasser et al. [8] described the symptoms of a child with thrombocytopenia, hemolytic anemia, and renal failure with bilateral diffuse cortical necrosis: this was called hemolytic uremic syndrome (HUS). In 1982 Moake et al. [9] suggested a defective processing of ultra-large von Willebrand factor (vWF) multimers produced by endothelial cells. In 1983, Karmali et al. [10] associated HUS with infections with Escherichia coli producing Shiga toxin (ST). According to Furlan et al. [11], increased proteolytic cleavage of vWF is observed in a number of cases with type $2 \mathrm{~A}$ von Willebrand disease. Large vWF multimers, which are hemostatically active, are degraded to form smaller and less active molecules. In particular, the peptide bond between $842 \mathrm{Tyr}$ and $843 \mathrm{Met}$ is cleaved in the polypeptide subunits of VWF. The increased frequency of platelet thrombosis in TTP patients is related to a deficiency of such proteolytic activity $[12,13]$. The key vWF-cleaving protease, on the basis of partial amino acid sequencing, was a large zinccontaining metalloprotease, identified as "a disintegrin and metalloproteinase with thrombospondin type 1", member 13 (ADAMTS13) of the ADAMTS protease family $[14,15]$.

\section{Epidemiology and Pathogenesis of TMA}

TMAs are rare diseases: five to ten cases/year per million cases of TTP are acquired, with a male:female ratio of $1: 2$ and a peak of incidence during the $4^{\text {th }}$ decade of life. Hereditary TTP represents one or fewer cases/year per million $[19,20]$.

The most prominent diagnoses associated with TMA are thrombotic TTP and HUS. They usually occur, respectively, in adults and in children. As discussed below, their pathogenesis is different: TP results from a severe ADAMTS13 deficiency, which can be caused by circulating autoantibodies or ADAMTS13 mutations, while HUS is correlated to infection with STproducing bacteria or gene mutations causing an excess of activation of the alternative pathway [16]. According to recent observations in TP/HUS registries, emerging features of these disorders are the diagnostic value of ADAMTS13 measurement, efficacy of plasma exchange (PEX), and frequency of relapses after remission $[17,18]$.

Many different disorders can cause TMA (i.e. secondary TMA; see below).

Other clinical TMA presentations are:

- HELLP syndrome (hemolysis, elevated liver enzymes, low platelet count), which is observed in a proportion of 0.5\%-0.9\% of pregnancies, as well as in 10\%-20\% of severe preeclampsia cases [21];

- catastrophic antiphospholipid syndrome, which is rarely observed patients with acute multi-organ thrombosis (less than $1 \%)$;

- malignant hypertension, in about 2.6 cases/year per 100,000 cases with a higher incidence among people of African descent;

- cancer: about 5\% of patients with disseminated malignancy;

- transplant-associated TMA following a) non-renal solid organ transplantation (incidence $5 \%, 4.0 \%$ in liver, $2.3 \%$ in lungs) $[22,23]$, b) renal transplantation, with 5.6/1000/year with a $50 \%$ mortality rate at three years [24], and c) hematopoietic progenitor cell transplantation, with variable ranges from $0 \%$ to $74 \%$ and median incidence of $7.9 \%[2,25]$. 
Finally, TMAs are also part of the pathology of disseminated intravascular coagulation (DIC), in which it results from the deposition of fibrin or platelets within the microvasculature [26], and scleroderma renal crisis [27]. In Table 1 the TMAs are listed according to cause.

This review mainly deals with diagnostic aspects of MAHA and TMAs. A number of clinical problems await solutions in TMA, such as the positioning of rituximab in the treatment sequence of primary TP, management of ST-producing Escherichia coliHUS complicated by encephalopathy, the efficacy and longterm safety of eculizumab in atypical HUS, and elucidation of the pathogenesis of secondary TMA $[28,29,30]$.

\section{Clinical Forms of TMA}

TTP is a clinical emergency with a mortality rate of up to $90 \%$ if not promptly treated [31]. African-Caribbean ancestry [32] and obesity [33] are risk factors. It is caused by a lack or deficiency of ADAMTS13. In normal individuals, endothelial cells produce vWF multimers from the Weibel-Palade bodies and the metalloprotease enzyme ADAMTS13 cleaves the unusually large multimers, avoiding platelet adhesion [34]. When the vWF multimers are not cleaved, platelets adhere and the endothelial layers of small vessels are damaged, causing platelet aggregation and fibrin deposition in microcirculation. Infections, drugs, and pregnancy/delivery $[35,36]$ may act as triggers in predisposed individuals. ADAMTS13 activity may be absent or highly inhibited by circulating autoantibodies, which represent the most frequent cause of acquired TT. Up to $75 \%$ of patients in the acute phase show the presence of IgG immunoglobulins with anti-ADAMTS13 activity, which inhibit its proteolytic activity towards vWF. Such autoantibodies circulate in the form of immuno-complexes (IC) and are the cause of the deficiency of ADAMTS13. In 20\%-25\% of patients anti-ADAMTS13 autoantibodies are not detectable, so that the mechanisms that underlie ADAMTS13 deficiency are not fully clarified. Less than 5\% of TTP cases are due to ADAMTS13 gene mutation (congenital TTP, Upshaw-Schulman syndrome (USS), an autosomal recessive disease presenting with early onset in childhood) $[37,38]$. More than 150 different ADAMTS13 gene mutations have been described to date: $70 \%$ of these mutations are missense, while the remaining 30\% are truncating [37]. In the suspicion of a congenital form of HUS, the ADAMTS13 level should be evaluated by measuring both its activity with a fluorogenic assay [39] and its antigen level to differentiate between type 1 (both activity and antigen decreased) and type 2 deficiency (severe activity defect associated with subnormal antigen level).

ST-mediated HUS is associated with the microbiological finding of Escherichia coli, mainly 0157:H7 and 0104:H4 serotypes, and/ or Shigella dysenteriae type 1 infection: the production of the ST leads to endothelial and glomerular damage with an acute clinical picture. It is usually caused by food, with a seasonal distribution with a summer peak, and it represents the main cause of acute renal impairment in children less than 3 years old. Enterohemorrhagic diarrhea self-resolves in most cases, but in 5\%-7\% of them, HUS develops a few days afterwards. ST, a pentamer of B subunits, causes endothelial cell damage through binding to a globotriaosylceramide receptor expressed on the membrane of endothelial cells: after internalization by endocytosis, ST inhibits protein synthesis, causing cell apoptosis and death [40] and exposure of the extracellular matrix with platelet aggregation, fibrin deposition, and mechanical hemolysis. The kidneys, gastrointestinal tract, and central nervous system (CNS) are the key target organs. ST-mediated HUS, which can be as severe as acute HUS, reaches a mortality rate of up to $5 \%$ [41].

Complement-mediated TMA presents with thrombocytopenia, mechanical hemolysis, and acute renal failure, with severe arterial hypertension and ischemic damage due to activation and/or abnormal regulation of the alternative pathway of the complement system on cell surfaces: mutations in $\mathrm{C} 3$ and factor $\mathrm{B}$; autoantibodies against factor $\mathrm{H}$ interfering with regulation;

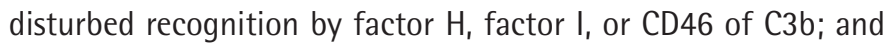
disturbed recognition by factor $\mathrm{H}$ of self-cell surface molecules,

Table 1. Thrombotic microangiopathies listed according to causes.

- Thrombotic thrombocytopenic purpura, ADAMTS13 deficiency-mediated:

- Genetic: <10\% ADAMTS13 activity

- Acquired: due to antibodies to ADAMTS13

- Shiga toxin-mediated hemolytic uremic syndrome, sustained by enteropathogenic microorganisms (Shigella dysenteriae and some serotypes of Escherichia coli, such as 0157:H7 and 0104:H4)

- Complement-mediated TMA, due to mutations in complement regulatory genes and/or antibodies blocking the complement functions

- Coagulation mediated TMA, due to mutations involving DGKE, PLG, and THBD genes

- Metabolism-mediated TMA due to mutations in MMACHC gene (methylmalonic aciduria and homocystinuria type C)

- Drug-mediated TMA via immunologic pathway (antibodies) and/or toxicity (quinine, ticlopidine, clopidogrel, interferon, contraceptives, etc.)

- Secondary TMAs: initiated by a coexisting disease or condition such as infection (Streptococcus pneumoniae infection, influenza virus), transplantation (solid organ or bone marrow), autoimmune disease, cancer, pregnancy, certain cytotoxic drugs (anticancer drugs, immunosuppressives), radiotherapy, malignant hypertension, disseminated intravascular coagulation, severe vitamin B12 deficiency, pancreatitis

TMA: Thrombotic microangiopathy. 
such as sialic acid or glycosaminoglycans [42]. About $20 \%$ of cases show a subclinical onset, with slow disease progression [43].

Coagulation-mediated TMA is caused by mutations of genes encoding for thrombomodulin (THBD), plasminogen (PLGX), and diacylglycerol kinase epsilon $(D G K E)$, inducing upregulation of prothrombotic factors $[44,45]$.

Metabolism-mediated TMA, usually seen in infants, is caused by mutations in different genes that cause methylmalonic and aciduria homocystinuria type $\mathrm{C}(\mathrm{MMACHC})$ [46].

Drug-mediated TMA [47] can be caused by:

- immune-mediated mechanisms with antibodies formation (quinine) [48].

- dose-dependent/toxicity mechanisms (cyclosporine, tacrolimus, clopidogrel, interferon, vascular endothelial growth factor inhibitor, mitomycin C).

- induction of drug-independent antibodies (ticlopidine).

New observations are not rare, such as TMA associated with the intravenous injection of adulterated Opana ER tablets [49].

Secondary TMAs are caused by different coexisting disorders, such as systemic infections [50]. In particular, infections due to Streptococcus pneumoniae and influenza viruses are considered true etiological factors, instead of simple triggers, of TMA. Cancer [51], transplantation of bone marrow or solid organs [52], autoimmune disease [53], pregnancy [54], cytotoxic drugs, DIC, severe deficiency of vitamin $B_{12}$ [55], and pancreatitis can be responsible for the development of secondary TMA. A common feature of the above-mentioned conditions is the generation of direct cell damage, with general activation of the complement system or enhanced activation of the complement on cell membranes [42].

\section{Diagnostic Tests}

Almost all cases of TMA are associated with MAHA. It is extremely important to exclude at a clinical level any possible cause of MAHA alternative to TMA. In particular, occasionally patients with paroxysmal nocturnal hemoglobinuria, intravascular and/or heart devices, heparin-induced thrombocytopenia, and systemic disorders such as systemic infections can present with MAHA in association with or without TMA. The main causes of secondary TMAs were mentioned above; the patient's history and physical examination are fundamental steps for the most appropriate diagnostic pathway. Diagnosis of MAHA is confirmed by negativity of DAT, increased LDH, and/or decreased haptoglobin. Organ involvement should be investigated. Complete blood count in MAHA shows normocytic anemia, reticulocytosis, and severe thrombocytopenia, while in the peripheral blood smear schistocytes, microspherocytes, and polychromatophilic RBCs, identifiable as immature reticulocytes by vital stains, are detected. Schistocytes are fragmented red cells appearing in a variety of shapes: rectangular, crescent, or helmet-shaped. Traditionally they are identified and counted by microscopic observation by trained laboratory scientists, with a large margin of error [3]. In TMA, RBCs are physically sheared by fibrin networks in the peripheral circulation: the appearance of schistocytes may be one of the earliest signs of TMA and its detection and quantitation are of primary importance. In 2012 the International Council for Standardization in Haematology published specific recommendations to standardize schistocyte identification, enumeration, and reporting [3], including morphological criteria for the identification of specific schistocyte types. Reference values are $\leq 0.1 \%$ in adults, $0.3 \%$ $1.9 \%$ in newborns, and $\leq 5.5 \%$ in preterms. Schistocytes should be evaluated on smears at medium microscope magnification as a percentage after counting at least 1000 red blood cells (Figure 1). Schistocyte count has definite clinical value for diagnosis of TMA in the absence of additional severe red cell shape abnormalities, with a confidence threshold value of 1\%. Fragmented RBC enumeration by automated counters is a complement to microscopy, providing rapid results with high predictive value for negative samples [3,4]. Increased megakaryocytes in bone marrow (Figure 2), usually with left shift, associated with thrombocytopenia testify to the presence of peripheral platelet consumption. Bone marrow aspiration is not mandatory but can facilitate the differential diagnosis (versus promyelocytic leukemias with DIC or other hypoplastic/ aplastic marrow diseases, including hemophagocytic syndrome).

Once primary TMA is confirmed, the type should be determined to provide the patient with the specific treatment: PEX in TTP and eculizumab in complement-mediated TMA. The patient's sample for assay of ADAMTS13 functional levels should be investigated.

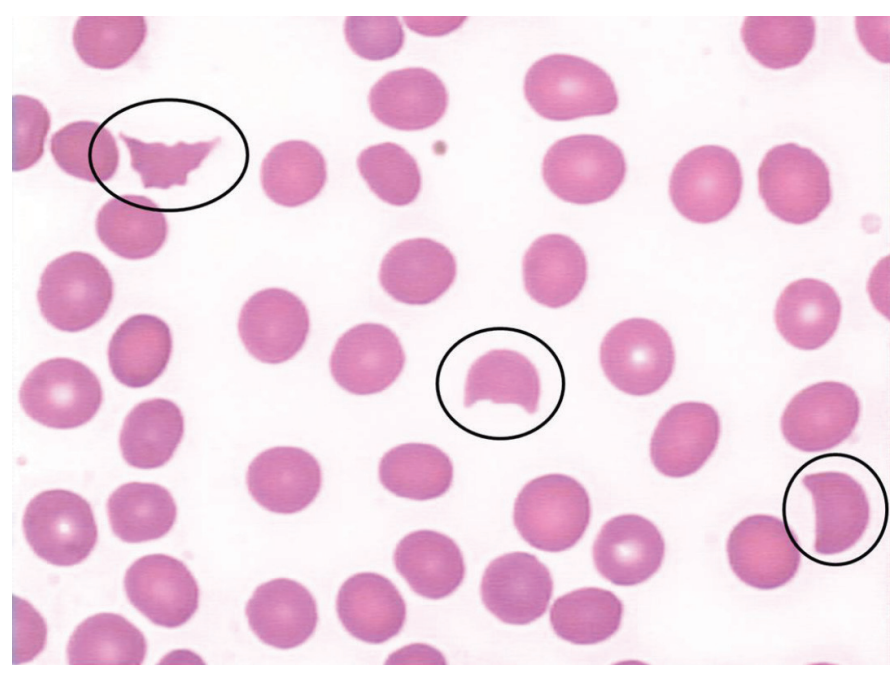

Figure 1. Schistocytes should be evaluated on smears at medium microscope magnification. 
ADAMTS13 activity measurements (degradation of a vWF substrate) are currently based on different methods [56]: fluorescence resonance energy transfer (FRET) [57], chromogenic enzyme-linked immunosorbent assay (ELISA) [58], mass spectrometry [59], and simplified methods based on coagulation analyzers [60].

Results of ADAMTS13 measurements are reported as a percentage of ADAMTS13 activity in pools of plasma from healthy donors, with a threshold of $<10 \%$. It is possible, however, in the opinion of these authors, that a lower threshold should be considered, given the increased sensitivity of newgeneration methodologies. An international World Health Organization standard plasma method for the measurement of ADAMTS13 has recently become available [61]. DNA testing for ADAMTS13 genes has also been developed [62].

Clinical interpretation is fundamental because of possible false low results due to hemolysis or increased bilirubin, especially in FRETS-based assays. Moreover, unfortunately results of the diagnostic tests are not immediately available, while patients with acute MAHA and thrombocytopenia usually require immediate treatment. In this scenario the PLASMIC score [63] does represent immediate help in calculating the diagnostic probability of TT, evaluating very simple parameters/information. One point is assigned to each of the following:

i) platelet count of $<30 \times 10^{9} / \mathrm{L}$;

ii) plasma or serum indirect bilirubin $>2 \mathrm{mg} / \mathrm{dL}$, or reticulocyte count $>2.5 \%$, or undetectable plasma haptoglobin,

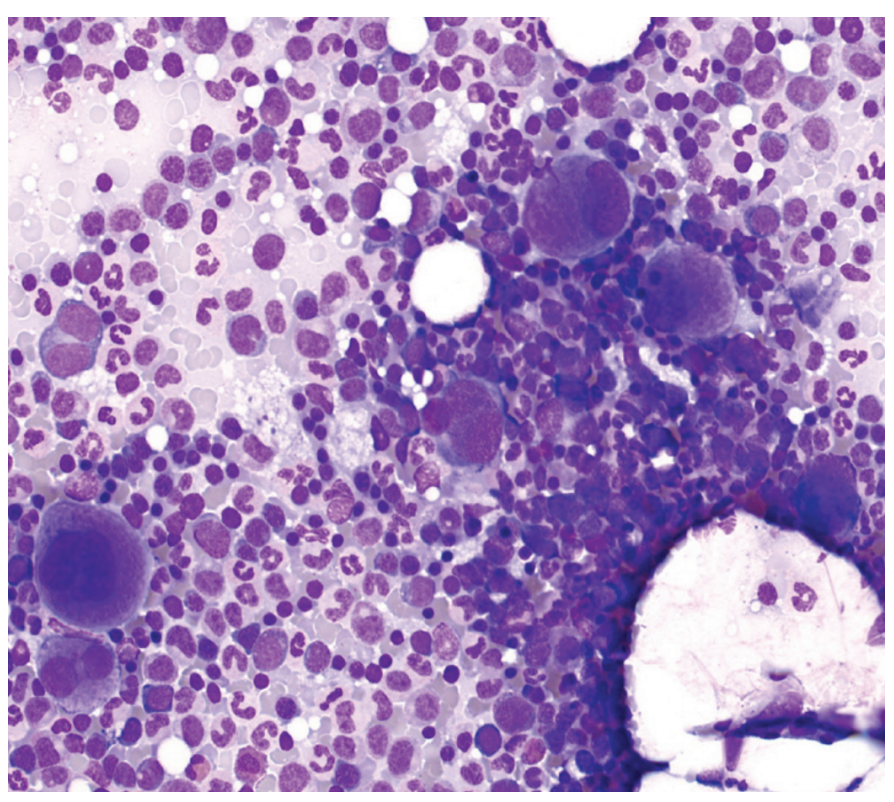

Figure 2. Increased megakaryocytes in bone marrow associated with thrombocytopenia testify to the presence of peripheral platelet consumption. iii) absence of active cancer,

iv) absence of solid organ or stem cell transplant in the medical history,

v) mean corpuscular volume (MCV) of $<90 \mathrm{fL}$,

vi) international normalized ratio (INR) $<1.5$,

vii) plasma or serum creatinine $<2.0 \mathrm{mg} / \mathrm{L}$.

The PLASMIC risk score for severe ADAMTS13 deficiency can be low $(<5)$, intermediate (5), or high ( $>5)$. ST-HUS acute onset is characterized by abdominal pain, associated with vomiting and bloody diarrhea, which can anticipate by several days other clinical and laboratory signs of MAHA associated with thrombocytopenia. Stool cultures for enteric pathogens do confirm the correct diagnosis. In complement-mediated TMA, symptoms are less typical, more insidious, and generic (acute renal failure, edema); up to $20 \%$ of cases present with multi-organ failure (CNS, cardiac, pulmonary, intestinal). It is reported as familial and sporadic, presenting in up to $80 \%$ of children and $50 \%$ of adults $[64,65]$. Quantitative, genetic, and functional complement assessment will lead to the diagnosis, and while waiting for lab test results it is mandatory to start treatment with PEX, moving to anticomplement therapy after obtaining the results. In drugmediated TMA, supportive therapy and drug discontinuation are indicated, while in metabolism-mediated TMA and coagulation-mediated TMA the role of molecular testing is fundamental. Figure 3 displays an algorithm for differential laboratory diagnosis in patients with clinical suspicion of TMA.

\section{Conclusion}

The differential diagnosis of TTP, HUS forms, and TMA from other etiologies can be challenging. Diagnosis has to be primarily based on clinical history (underlying disease, medications). In intensive care patients, TMA is more probably associated with the underlying illnesses. In patients presenting with TMA signs, clinical antecedents of metastatic malignancy, hypertension, polychemotherapy or immunosuppressive treatment, HELLP syndrome, or allogeneic stem cell transplant should be considered as possible causes for the TMA presentation. In the great majority of such patients, a serum level of ADAMTS13 activity lower than $10 \%$ is a useful element for the differential diagnosis. Finally, not infrequently diagnostic assessment has to be extended after treatment and recovery of patients, especially when biochemical and molecular biology studies, including mutation analysis of complement factors, may add useful elements. 


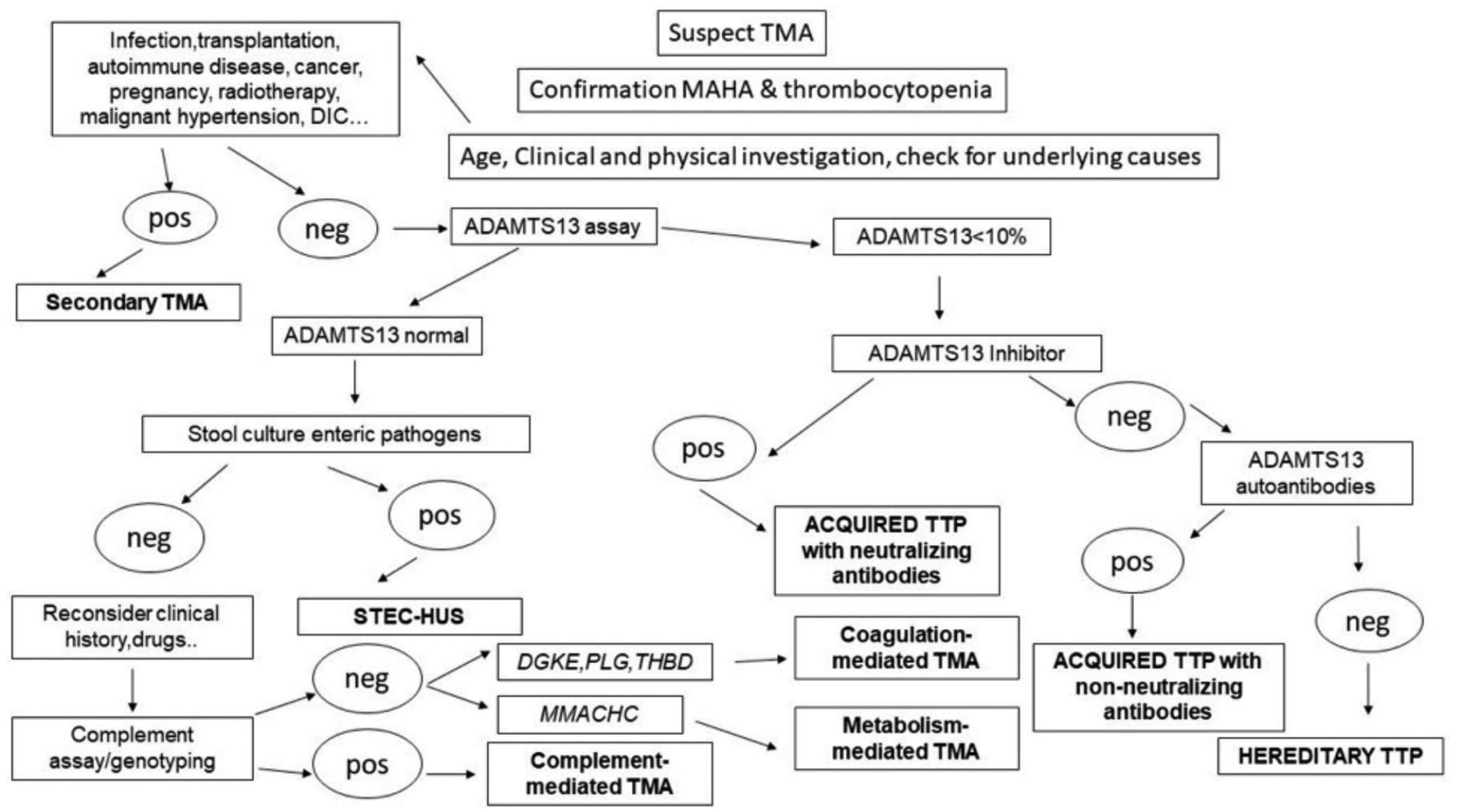

Figure 3. Algorithm for differential laboratory diagnosis in patients with clinical suspicion of thrombotic microangiopathie.

\section{Ethics}

Ethics Committee Approval: Not appliable to a review.

\section{Authorship Contributions}

Surgical and Medical Practices: G.Z., R.D.C.; Concept: G.Z., R.D.C.; Design: G.Z., R.D.C.; Literature Search: G.Z.; Writing: G.Z.

Conflict of Interest: The authors of this paper have no conflicts of interest, including specific financial interests, relationships, and/or affiliations relevant to the subject matter or materials included.

\section{References}

1. George JN, Nester CM. Syndromes of thrombotic microangiopathy. N Engl J Med 2014;371:654-666.

2. George JN, Selby GB. Thrombotic microangiopathy after allogeneic bone marrow transplantation: a pathologic abnormality associated with diverse clinical syndromes. Bone Marrow Transplant 2004;33:1073-1074.

3. Zini G, d'Onofrio G, Briggs C, Erber W, Jou JM, Lee SH, McFadden S, VivesCorrons JL, Yutaka N, Lesesve JF; International Council for Standardization in Haematology (ICSH). ICSH recommendations for identification, diagnostic value, and quantitation of schistocytes. Int J Lab Hematol 2012;34:107-116.

4. Schapkaitz $E_{1}$ Mezgebe MH. The clinical significance of schistocytes: a prospective evaluation of the International Council for Standardization in Hematology schistocyte guidelines. Turk J Hematol 2017;34:59-63.

5. Moschcowitz E. Hyaline thrombosis of the terminal arterioles and capillaries: a hitherto undescribed disease. Proc N Y Pathol Soc 1924;24:21-24.
6. Singer K, Bornstein FP, Wiles SA. Thrombotic thrombocytopenic purpura; hemorrhagic diathesis with generalized platelet thromboses. Blood $1947 ; 2: 542-554$.

7. Symmers WS. Thrombotic microangiopathic haemolytic anemia (thrombotic microangiopathy). Br Med J 1952;2:897-903.

8. Gasser C, Gautier E, Steck A, Siebenmann RE, Oechslin R. Hemolyticuremic syndrome: bilateral necrosis of the renal cortex in acute acquired haemolytic anemia. Schweiz Med Wochenschr 1955;85:905-909.

9. Moake JL, Rudy CK, Troll JH, Weinstein MJ, Colannino NM, Azocar J, Seder $\mathrm{RH}$, Hong SL, Deykin D. Unusually large plasma factor VIII:von Willebrand factor multimers in chronic relapsing thrombotic thrombocytopenic purpura. N Engl J Med 1982;307:1432-1435.

10. Karmali MA, Steele BT, Petric M, Lim C. Sporadic cases of haemolyticuraemic syndrome associated with faecal cytotoxin and cytotoxinproducing Escherichia coli in stools. Lancet 1983;1:619-620.

11. Furlan $M$, Robles $R$, Lämmle B. Partial purification and characterization of a protease from human plasma cleaving von Willebrand factor to fragments produced by in vivo proteolysis. Blood 1996;87:4223-4234.

12. Tsai HM, Lian EC. Antibodies to von Willebrand factor-cleaving protease in acute thrombotic thrombocytopenic purpura. N Engl J Med 1998;339:15851594.

13. Furlan $M$, Robles $R$, Galbusera $M$, Remuzzi $G$, Kyrle PA, Brenner B, Krause $M$ Scharrer I, Aumann V, Mittler U, Solenthaler M, Lämmle B. von Willebrand factor-cleaving protease in thrombotic thrombocytopenic purpura and the hemolytic-uremic syndrome. N Engl J Med 1998;339:1578-1584.

14. Zheng X, Chung D, Takayama TK, Majerus EM, Sadler JE, Fujikawa K. Structure of von Willebrand factor-cleaving protease (ADAMTS13), a metalloprotease involved in thrombotic thrombocytopenic purpura. J Biol Chem 2001;276:41059-41063.

15. Levy GG, Nichols WC, Lian EC, Foroud T, McClintick JN, McGee BM, Yang AY Siemieniak DR, Stark KR, Gruppo R, Sarode R, Shurin SB, Chandrasekaran 
V, Stabler SP, Sabio H, Bouhassira EE, Upshaw JD Jr, Ginsburg D, Tsai HM. Mutations in a member of the ADAMTS gene family cause thrombotic thrombocytopenic purpura. Nature 2001;413:488-494.

16. Kremer Hovinga JA, Heeb SR, Skowronska M, Schaller M. Pathophysiology of thrombotic thrombocytopenic purpura and hemolytic uremic syndrome. J Thromb Haemost 2018;16:618-629.

17. Page EE, Kremer Hovinga JA, Terrell DR, Vesely SK, George JN. TTP: diagnostic criteria, clinical features, and long-term outcomes from 1995 through 2015. Blood Adv 2017;1:590-600.

18. van Dorland HA, Mansouri Taleghani M, Sakai K, Friedman KD, George JN, Hrachovinova I, Knöbl PN, von Krogh AS, Schneppenheim R, Aebi-Huber I, Bütikofer L, Largiadèr CR, Cermakova Z, Kokame K, Miyata T, Yagi H, Terrell DR, Vesely SK, Matsumoto M, Lämmle B, Fujimura Y, Kremer Hovinga JA; Hereditary TTP Registry. The International Hereditary TTP Registry: Key findings at enrolment until 2017. Haematologica 2019.

19. Terrell DR, Williams LA, Vesely SK, Lämmle B, Hovinga JA, George JN. The incidence of thrombotic thrombocytopenic purpura-hemolytic uremic syndrome: all patients, idiopathic patients, and patients with severe ADAMTS-13 deficiency. J Thromb Haemost 2005;3:1432-1436.

20. Rafat C, Coppo P, Fakhouri F, Frémeaux-Bacchi V, Loirat C, Zuber J, Rondeau E. Hemolytic and uremic syndrome and related thrombotic microangiopathies: epidemiology, pathophysiology and clinics. Rev Med Int 2017;38:817-824.

21. George JN. The association of pregnancy with thrombotic thrombocytopenic purpura-hemolytic uremic syndrome. Curr Opin Hematol 2003;10:339-344.

22. Lohrmann HP, Adam W, Heymer B, Kubanek B. Microangiopathic hemolytic anemia in metastatic carcinoma. Report of eight cases. Ann Intern Med 1973;79:368-375

23. Moake JL. Thrombotic microangiopathies. N Engl J Med 2002;347:589-600.

24. Abbas F, El Kossi M, Kim JJ, Sharma A, Halawa A. Thrombotic microangiopathy after renal transplantation: current insights in de novo and recurrent disease. World J Transplant 2018;8:122-141.

25. Ruutu T, Barosi G, Benjamin RJ, Clark RE, George JN, Gratwohl A, Holler $E$, lacobelli $M$, Kentouche $K$, Lämmle $B$, Moake JL, Richardson $P$, Socié G, Zeigler Z, Niederwieser D, Barbui T; European Group for Blood and Marrow Transplantation; European LeukemiaNet. Diagnostic criteria for hematopoietic stem cell transplant-associated microangiopathy: results of a consensus process by an International Working Group. Haematologica 2007;92:95-100.

26. Toh $\mathrm{CH}$, Alhamdi $\mathrm{Y}$, Abrams ST. Current pathological and laboratory considerations in the diagnosis of disseminated intravascular coagulation. Ann Lab Med 2016;36:505-512.

27. Woodworth TG, Suliman YA, Furst DE, Clements P. Scleroderma renal crisis and renal involvement in systemic sclerosis. Nat Rev Nephrol 2016;12:678691.

28. Neave L, Gale DP, Cheesman S, Shah R, Scully M. Atypical haemolytic uraemic syndrome in the eculizumab era: presentation, response and evaluation of an eculizumab withdrawal strategy. Br J Haematol 2019;186:113-124.

29. Elemary M, Sabry W, Seghatchian J, Goubran H. Transplant-associated thrombotic microangiopathy. Transfus Apher Sci 2019;58:347-350.

30. Berger BE. Atypical hemolytic uremic syndrome: a syndrome in need of clarity. Clin Kidney J 2018;12:338-347.

31. Deford CC, Reese JA, Schwartz LH, Perdue JJ, Kremer Hovinga JA, Lämmle B, Terrell DR, Vesely SK, George JN. Multiple major morbidities and increased mortality during long-term follow-up after recovery from ПТ. Blood 2013;122:2023-2029.

32. Reese JA, Muthurajah DS, Kremer Hovinga JA, Vesely SK, Terrell DR, George JN. Children and adults with TP associated with severe, acquired ADAMTS13 deficiency: comparison of incidence, demographic and clinical features. Pediatr Blood Cancer 2013;60:1676-1682.
33. Hrdinová J, D'Angelo S, Graça NAG, Ercig B, Vanhoorelbeke K, Veyradier A, Voorberg J, Coppo P. Dissecting the pathophysiology of immune TP: interplay between genes and environmental triggers. Haematologica 2018;103:1099-1109.

34. Di Stasio E, Lancellotti S, Peyvandi F, Palla R, Mannucci PM, De Cristofaro R. Mechanistic studies on ADAMTS13 catalysis. Biophys J 2008;95:2450-2461.

35. Pourrat 0 , Coudroy R, Pierre F. Differentiation between severe HELLP syndrome and thrombotic microangiopathy, thrombotic thrombocytopenic purpura and other imitators. Eur J Obstet Gynecol Reprod Biol 2015;189:6872.

36. Fakhouri F. Pregnancy-related thrombotic microangiopathies: clues from complement biology. Transfus Apher Sci 2016;54:199-202.

37. Lancellotti S, De Cristofaro R. Structure and proteolytic properties of ADAMTS13, a metalloprotease involved in pathogenesis of thrombotic microangiopathies. Prog Mol Biol Transl Sci 2011;99:105-144.

38. Lancellotti S, Peyvandi F, Pagliari MT, Cairo A, Abdel-Azeim S, Chermak E, Lazzareschi I, Mastrangelo S, Cavallo L, Oliva R, De Cristofaro R. The D173G mutation in ADAMTS-13 causes severe form of congenital thrombotic thrombocytopenic purpura. A clinical, biochemical and in silico study. Thromb Haemost 2016;115:51-62.

39. Palla $R$, Valsecchi $C$, Bajetta $M$, Spreafico $M$, De Cristofaro $R$, Peyvandi $F$. Evaluation of assay methods to measure plasma ADAMTS13 activity in thrombotic microangiopathies. Thromb Haemost 2011;105:381-385.

40. Pacheco AR, Sperandio V. Shiga toxin in enterohemorrhagic E. coli: regulation and novel anti-virulence strategies. Front Cell Infect Microbiol 2012;2:81

41. Kielstein JT, Beutel G, Fleig S, Steinhoff J, Meyer TN, Hafer C, Kuhlmann U, Bramstedt J, Panzer U, Vischedyk M, Busch V, Ries W, Mitzner S, Mees $S$, Stracke $S$, Nürnberger J, Gerke $P$, Wiesner M, Sucke B, Abu-Tair M, Kribben A, Klause N, Schindler R, Merkel F, Schnatter S, Dorresteijn EM, Samuelsson 0, Brunkhorst R; Collaborators of the DGfN STEC-HUS registry. Best supportive care and therapeutic plasma exchange with or without eculizumab in Shiga-toxin-producing E. coli 0104:H4 induced haemolyticuraemic syndrome: an analysis of the German STEC-HUS registry. Nephr Dial Transplant 2012;27:3807-3815.

42. Jokiranta TS. HUS and atypical HUS. Blood 2017;129:2847-2856.

43. Nester CM, Barbour T, de Cordoba SR, Dragon-Durey MA, Fremeaux-Bacchi V, Goodship TH, Kavanagh D, Noris M, Pickering M, Sanchez-Corral $P$, Skerka C, Zipfel P, Smith RJ. Atypical aHUS: state of the art. Mol Immunol 2015;67:31-42.

44. Quaggin SE. DGKE and atypical HUS. Nat Genet 2013;45:475-476.

45. Bu F, Maga T, Meyer NC, Wang $K$, Thomas CP, Nester CM, Smith RJ. Comprehensive genetic analysis of complement and coagulation genes in atypical hemolytic uremic syndrome. J Am Soc Nephrol 2014;25:55-64.

46. Geraghty MT, PerIman EJ, Martin LS, Hayflick SJ, Casella JF, Rosenblatt DS, Valle D. Cobalamin C defect associated with hemolytic-uremic syndrome. J Pediatr 1992;120:934-937.

47. Al-Nouri ZL, Reese JA, Terrell DR, Vesely SK, George JN. Drug-induced thrombotic microangiopathy: a systematic review of published reports. Blood 2015;125:616-618.

48. Glynne P, Salama A, Cahudhry A, Swirsky D, Lightstone L. Quinine-induced immune thrombocytopenic purpura followed by hemolytic uremic syndrome. Am J Kidney Dis 1999;33:133-137.

49. Hunt R, Yalamanoglu A, Tumlin J, Schiller $T$, Baek JH, Wu A, Fogo AB, Yang $H$, Wong $E$, Miller $P$, Buehler PW, Kimchi-Sarfaty C. A mechanistic investigation of thrombotic microangiopathy associated with IV abuse of Opana ER. Blood 2017;129:896-905.

50. Booth KK, Terrell DR, Vesely SK, George JN. Systemic infections mimicking thrombotic thrombocytopenic purpura. Am J Hematol 2011;86:743751. 
51. Morton JM, George JN. Microangiopathic hemolytic anemia and thrombocytopenia in patients with cancer. J Oncol Pract 2016;12:523530

52. Laskin BL, Goebel J, Davies SM, Jodele S. Small vessels, big trouble in the kidneys and beyond: hematopoietic stem cell transplantation-associated thrombotic microangiopathy. Blood 2011;118:1452-1462.

53. Song $D$, Wu LH, Wang FM, Yang XW, Zhu D, Chen M, Yu F, Liu G, Zhao $\mathrm{MH}$. The spectrum of renal thrombotic microangiopathy in lupus nephritis. Arthritis Res Ther 2013;15:12.

54. McMinn JR, George JN. Evaluation of women with clinically suspected thrombotic thrombocytopenic purpura-hemolytic uremic syndrome during pregnancy. J Clin Apher 2001;16:202-209.

55. Grangé $S$, Bekri $S$, Artaud-Macari E, Francois A, Girault C, Poitou AL, Benhamou Y, Vianey-Saban C, Benoist JF, Châtelet V, Tamion F, Guerrot D. Adult-onset renal thrombotic microangiopathy and pulmonary arterial hypertension in cobalamin C deficiency. Lancet 2015;386:1011-1012.

56. Joly BS, Coppo P, Veyradier A. Thrombotic thrombocytopenic purpura. Blood 2017; 129:2836-2846.

57. Kokame $K$, Nobe $Y$, Kokubo $Y$, Okayama A, Miyata T. FRETS-VWF73, a first fluorogenic substrate for ADAMTS13 assay. Br J Haematol 2005;129:93100.

58. Kato $S$, Matsumoto $M$, Matsuyama $T$, Isonishi $A$, Hiura $H$, Fujimura $Y$. Novel monoclonal antibody-based enzyme immunoassay for determining plasma levels of ADAMTS13 activity. Transfusion 2006;46:1444-1452.

59. Jin $\mathrm{M}$, Cataland $\mathrm{S}$, Bissell $\mathrm{M}, \mathrm{Wu} \mathrm{HM}$. A rapid test for the diagnosis of thrombotic thrombocytopenic purpura using surface enhanced laser desorption/ionization time-of-flight (SELDI-TOF)-mass spectrometry. J Thromb Haemost 2006;4:333-338.

60. Knovich MA, Craver K, Matulis MD, Lawson $\mathrm{H}$, Owen J. Simplified assay for VWF cleaving protease (ADAMTS13) activity and inhibitor in plasma. Am J Hematol 2004;76:286-290.

61. Hubbard $A R$, Heath $A B$, Kremer Hovinga $J A$; Subcommittee on von Willebrand Factor. Establishment of the WHO 1st International Standard ADAMTS13, plasma (12/252): communication from the SSC of the ISTH. J Thromb Haemost 2015;13:1151-1153.

62. Fidalgo $T$, Martinho $P$, Pinto $C S$, Oliveira $A C$, Salvado $R$, Borràs $N$, Coucelo $M$, Manco L, Maia T, Mendes MJ, Del Orbe Barreto R, Corrales I, Vidal F, Ribeiro ML. Combined study of ADAMTS13 and complement genes in the diagnosis of thrombotic microangiopathies using next-generation sequencing. Res Pract Thromb Haemost 2017;1:69-80.

63. Bendapudi PK, Hurwitz S, Fry A, Marques MB, Waldo SW, Li A, Sun L, Upadhyay V, Hamdan A, Brunner AM, Gansner JM, Viswanathan S, Kaufman RM, Uhl L, Stowell CP, Dzik WH, Makar RS. Derivation and external validation of the PLASMIC score for rapid assessment of adults with thrombotic microangiopathies: a cohort study. Lancet Haematol 2017;4:157-164.

64. Noris M, Caprioli J, Bresin E, Mossali C, Pianetti G, Gamba S, Daina E, Fenili C, Castelletti F, Sorosina A, Piras R, Donadelli R, Maranta R, van der Meer I, Conway EM, Zipfel PF, Goodship TH, Remuzzi G. Relative role of genetic complement abnormalities in sporadic and familial aHUS and their impact on clinical phenotype. Clin J Am Soc Nephrol 2010;5:1844-1859.

65. Kottke-Marchant K. Diagnostic approach to microangiopathic hemolytic disorders. Int J Lab Hematol 2017;39(Suppl 1):69-75. 